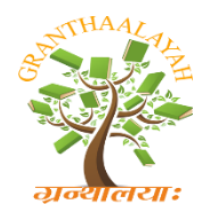
INTERNATIONAL JOURNAL OF RESEARCH - GRANTHAALAYAH
A knowledge Repository

Social

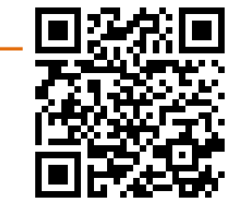

\title{
TEACHERS' ROLES ON ENGLISH LANGUAGE TEACHING: A STUDENTS CENTERED LEARNING APPROACH
}

\author{
Lamhot Naibaho ${ }^{* 1}$ \\ ${ }^{* 1}$ Universitas Kristen Indonesia
}

\begin{abstract}
This study is about teachers' roles on english language teaching viewed from the perspective of students centered learning approach, and it is aimed at investigating the teachers' roles in teaching the language to the students based on students centered learning activity and enlarging the knowledge of the language teachers' roles in teaching in order to help them to be more professional in their field. The method of the study used in this study was a library research study, where theories from any sources that related to the theory used in this study, were used to provide the answers of the problem of this study. The instruments of this study were books and documents. The results of this study indicated that there are some roles that must be possessed by the teacher during language teaching, such as: an organizer, an assessor, a prompter, a participant, a resource, a tutor, an observer, a performer, a controller and as teaching aid. It can be concluded that in order to succeed the language teaching based on students centered learning approach, a teacher should implement those roles.
\end{abstract}

Keywords: Role; Language Teaching; Teacher; Students Centered; Approach.

Cite This Article: Lamhot Naibaho. (2019). "TEACHERS' ROLES ON ENGLISH LANGUAGE TEACHING: A STUDENTS CENTERED LEARNING APPROACH.” International Journal of Research - Granthaalayah, 7(4), 206-212. 10.29121/granthaalayah.v7.i4.2019.892.

\section{Introduction}

A lot of things can be done in order to create a context for the teaching of useful language, but it all depends on the teacher as a decision maker to which direction the lesson will be directed in the classroom, which obviously no teacher expects his learning in the classroom to be meaningless. It is clear that if a teacher is in such a position that him being in the classroom does not bring positive change, it means that he is not a successful teacher or even a failed teacher. A teacher has been prepared in advance long before he runs out to be a teacher or let it be so, when a person wants to become a teacher, he has to prepare himself to be a teacher both mentally and physically and also in terms of knowledge. If this does not exist in a person's person when he wants to be a teacher then clearly I say do not choose a teacher profession. Because your presence in the presence of students will be a burden for yourself and even the students. 
Being a teacher is not easy, although it seems easy because behind all that we see it happens a lot of problems both in terms of curriculum, delivery of material and even personal students we are teaching a very diverse. If we can not respond to this in a professional way then we will eventually become the person who may be burdened with all that so we choose to give up. For that before we experience such things should think first before we choose the profession to be a teacher. The bad behavior of a teacher will be an example for the students, when he enters the class and presents the subject matter, all students will see him as well as identify them as he looks, behaves and acts. The teaching of a teacher will reflect the social philosophy of the outer society, and when it changes the society's view of the teacher will change. ${ }^{1,2}$ Teachers should be able to present the best in front of the students, as Harmer says "a good teacher is a teacher who is able to absorb unexpected things and use them for the good of the students". 3

This paper aims to describe the role of teachers in language teaching, in which the teacher's role in this paper will be explained from several sources which will be explained in detail one by one. Hopefully this paper can be useful for those of us who work as educators and open our insight to know our true role in language teaching.

Teacher is a person whose proffession is teaching or transfering knowledge to the other. Teacher as someone who works at school or at college or institutional-educational institutions. ${ }^{4}$ While everyday if we ask the understanding of teachers in those who work as teachers, then we will listen to various answers, in defining who the teacher, they tend to use methaphorical expression as Harmer said in his book when he asked some teachers. A teacher says "teacher is an actor" because he said the teacher is always on stage. The other teacher says "teacher is like an orchestra conductors" because the teacher directs the conversation and also the sound of language intonation. There is also a saying "teacher is like a gardener" because the teacher planted the seed and paid attention to the growth of the seed. The more imagery teachers use to describe them, the more views they have about their profession. ${ }^{5,6}$ The profession of a teacher is a profession that has a lot of responsibility, and that responsibility is not an easy responsibility to do. In contrast to other occupations that have responsibilities that are only responsible between him and the leader. Teachers are not, they must be responsible to guide the students in the right direction and guide them to be able to understand or know something. This should be accountable to the leadership, government and society. As Harmer points out, the responsibility of teachers is not only in education but also in the classroom.

Teachers are a key factor in the successful implementation of curriculum change. ${ }^{7}$ Which means that teachers are the key to success in the implementation of curriculum change. Teachers must have extraordinary competence in their teacher, in everyday teaching all teachers have differences and differences or variations of teacher teaching in the classroom we can see in the following dimensions: a) the proficiency of language); b) the teaching experiences; c) the ability and expertise; d) the training and qualification; e) the moral and motivation; f) the teaching technique; and $\mathrm{g}$ ) biliefs and principles.

The author is very interested to hear the proverbs written by an expert who says "If the teacher is indeed wise, he does not bid you enter the house of his wisdom, but rather leads you to the treshold of your own mind". ${ }^{8,9,10}$ From this sentence we can know that a teacher who is really smart is a teacher who never ordered his students to be in the arena of his wisdom, but a good teacher is a 
good teacher who guides his students to be able to feel his own thoughts. From that definition we can not force the students to be like us but we must try to make them understand that they are unique human beings who have a high level of intellectual and incredible mind power that has not been fully utilized by them. Is teaching done by teachers just simply transfer science to students? In other words, does the teacher just stand in front and watch what is happening amongst his students? Or do teachers just go for a walk among students and help those who are troubled only when they need it? The answers to these three questions are of course "no" because the benchmarks of good learning are not on the teacher's performance but the activities of the students occur and are beneficial. Such physical manifestations must occur in the classroom where the students are given the task to do and when the task is done (with the help of an excellent teacher) the actual learning takes place. In such situations the position of the teacher is not as a giver of knowledge, not as a controller, or even a ruler, but a facilitator.

\section{Method}

The method of the study used in this study was a library research method, where theories from any sources that related to the theory used in this study, were used to provide the answers to the problem of this study. ${ }^{11,12,113}$ The instruments of this study were books and documents and journals. ${ }^{14,15,16,17}$ It was done at Christian University of Indonesia from January - March, 2017. The data analysis technique used in this study was descriptive qualitative technique.

\section{Result and Discussion}

In learning the language in the classroom or outside the classroom, the role we play may vary in doing one activity to another activity. When we have been good in making this change, automatically our effectiveness as a language teacher will increase. As I mentioned earlier, that in some of the activities we do in the classroom, a teacher may act as a facilitator, and many other teacher roles will be described in this section. All roles played by a teacher in language learning aim to facilitate student development so that it needs to be applied appropriately.

Furthermore each of each teacher's role will be described in full as below but in this case, the authors focus more on describing the role of teachers according to exposure that has been exposed by Harmer because of among the many sources that examine neighboring teacher's role in the classroom, the theory which Harmer possesses more fully even though this paper also discusses the role of teachers based on other theories. So the role of the teacher according to his theory of Harmer is as follows:

Teacher as Controller: In this case the teacher is the one who served as the controller, and when the teacher acts as a controller, they are responsible in the class and also responsible for all activities that occur in the classroom. In this case the teacher plays a role, tells the students who need to be informed, organizes the exercises, reads loud and the other role is to give an example or show how to do something with good quality to the students. Teachers who usually only perceive their work as a transfer of knowledge they have to students are usually very comfortable with the role of controller. Many students can remember teachers in their past who only gave instructions and who have inspired their students with the knowledge and charisma they have. However, not all teachers have the ability to inspire students. There are certain times for the teacher 
to perform his role as a controller, such as when making announcements, while restoring circumstances, while giving explanations, or when a teacher is leading question and answer in the classroom. In fact, this role is the most we find in every language learning that happens. Not all teachers in their role play in the classroom can be right, because basically they just enjoy the role sebgai controller.

Teacher as Organizer: Acting as an organizer in language learning in the classroom is one of the most important roles, in which case the teacher must organize the students as well as the very diverse activities in language learning. Usually activities in this field are to provide information to students, telling them how to do things, varying their study groups either in pairs or groups and finally ending something typed something that ends or finishes. This role is very important to be played by a teacher when in a timely manner. For example, when students do not understand what they should be doing, they may not benefit from the ongoing activities or from the teacher's role as an organizer. The main thing we pay attention to in organizing something is to get students involved and ready in all the activities we organize. Or in other words can be said when something new will be done, make sure that the activity is interesting and good activity for us. In this case also a teacher must be creative in informing the activities that will be done, meaning that when conveyed to students teachers should be able to attract their attention so that they can anthusias in doing these new activities. When students are ready for activities, this is where we will guide them in doing their activities with instructions either directly or indirectly. It is also possible to conduct a demonstration against students in terms of testing their level of understanding in doing something.

Teacher as an Assessor: One of the things students expect from their teachers is an indication that they are right or wrong when they speak the language they are learning. In this case we act as assessors. This means that as a teacher we have to offer feedback to students as they speak and correct their mistakes in using the language and assess them in a variety of ways. Students also need to know how and for what they are assessed. We have to tell you what we are looking for and how far they have succeeded so that they can compare their abilities from what we have told them. As one example, when we want to judge something then we can say "Okay now we are going to practice the conversation in pairs so choose each pair, then make a conversation with the topic of travel. You need to know what I value from this conversation is the correct speech and grammar "from the notice students will know to which areas they should concentrate. In the case of penilain also we need to know the problem of honesty in assessing. Students can also know whether we are fair in judgment or not so if we have limited our judgment to where we focus focus then we should try as objectively as possible. Because with a non-objective assessment will also affect the interest of learning the language of students.

Teacher as Prompter: In this case, the teacher has a role as a whisperer. For example in an activity or in a presentation. Students are silent do not remember what to say or just say they ran out of vocabulary when going to say something. This is where the teacher's role as a prompter can be applied. For example, in the case above, whether the teacher let them until they remember or can find the right words typed would say something. Or does the teacher clue so they can say it or even the teacher immediately tells the word they need it? In this case also a teacher should be wise. For example when writing, a teacher asks students the reason why they wrote it. After that the students 
will give a reason but it is very difficult to get started. Teachers may provide words that can help him find answers to the teacher's questions.

Teacher as Participant: A tradition that often occurs during a discussion, or a student's role play is ongoing is the teacher as the organizer of the activities in the class just interferes with the affairs or simply gives feedback to the students or even justifies the wrong when after the discussion is over. But basically, there are also certain times where we should not be teachers but partispan. There are several reasons that support us sometimes have to act as participants, as Harmer says that we can enliven things from the inside instead of promoting or organizing from outside the group. When it goes well, students enjoy having the teacher with them, and for the teacher, participating is often more enjoyable then acting as a resource. Which means that as a teacher who acts as a participant can create a lively atmosphere in the discussion rather than just as a source of information. Thus, when it succeeds students can enjoy their togetherness with the teacher, and for the teacher, teacher participation is an instant pleasure rather than a role as a source. But nevertheless, there remains the danger when a teacher acts as a participant, in which the teacher may be the master in the discussion. Therefore, the role of teachers as participant is a role that is included in the category difficult to do, meaning to avoid it then we must have a strong ability and high sensitive.

Teacher as a Resource: In some cases, we do not need to apply the previously described roles. For example, when students are writing, or when they are involved in the presentation preparation that will be presented in the classroom. or control them. In that case, the role of the teacher or when the teacher tries to control them, or try to encourage them, they will likely not welcome us. Because in that case they need us as a source. Because of the possibility of students may ask how to express something or ask the meaning of a word or phrase that they have not understood. Chances are they also want to know information from something in the middle of the discussion they are doing. For example from where they will get information about something that has been assigned to them, from the book or from the web. In this case our role as a source of information is needed. When we act as a source, we must have a sense of help as well as readiness in performing this role. Because at the same time we also must be able mengthankan desire to meet the needs of students so that in the end they can trust to us.

Teacher as a Tutor: When students are working on a longer project, such as writing or preparing for discussion or debate, this is where a teacher acts as a tutor, working with a private or a small group, pointing them one at a time. In such situations, we are merging teacher roles as prompter and resource, and acting as tutors. Being a tutor is a very difficult role to do in a class that has a large number of students because it indirectly must have an intimate relationship with students. However, when students are working in groups or in pairs, we can walk around and pause with some groups or partners and offer some guidance or direction in doing what we tell them to do. Perth death must remain and all must be evenly distributed, however, all the groups or couples we have formed should feel our attention as tutors and otherwise the group or couple we ignore will feel sad. We have to play the role of a continuous tutor even though it is difficult because with a more specific context with students, we have the right opportunity to help and encourage so that the atmosphere in the class is awakened very well as a result. 
Teacher as an observer: In the process of carrying out observations, be careful, not be a nuisance by hanging all their questions by being close to them. This means that in practice, we should not interfere with what he is doing means that we are just as an observer, and should not give input to them. The things needed to observe that we need to bring a notebook and pen to assess student performance either collectively or individually. Teachers here not only observe students to provide feedback. They should also pay close attention to the success of the teaching materials and the activities they deliberately carry in the classroom so that they can all, and if necessary we should prepare food during the observation process.

The teacher as performer: Having learned that different teachers, acting are also different, and that they have different behaviors. It depends on what they will do. Suggestions, even though the teacher tells us which part to play, we should also be able to describe how they can play. Therefore, in an activity where students engage in a team game, it is appropriate that we act full of energy, encouragingly, clearly, and fairly.

Example:

\begin{tabular}{|l|l|}
\hline Activity & How the teacher should perform \\
\hline Team game & Energetically, encouragingly, clearly, fairly \\
\hline Role-play & Clearly, encouragingly, retiringly, supportively \\
\hline Teacher and reading Aloud & Commandingly, dramatically, interstingly \\
\hline Whole-Class Listening & Efficiently, clearly and supportively. \\
\hline
\end{tabular}

The Teacher as a Teaching Aid: Regardless of the roles we adopt in the classroom and how these roles are applied, our teachers are also aids. In particular, we are actually very useful when all of us, using clowns or body movements, as language models, and as a provider of understandable input. According to Brown, the effective role of teachers in the classroom is as a facilitator, manager, director, conductor or teacher as a source. Richard \& Rodger state that the role or teacher is three. First, at the presentation stage the teacher acts as a model, by setting the situation and modeling the new structure that students must repeat over and over again. the two teachers seemed to be like a conductor of an orchestra show that directs a musician in a harmonious sound. Third, teachers are required to be talented manipulators by using questions, orders, and other clues to provoke appropriate sentences from students.

\section{Conclusion and Recomendation}

In the classroom, teachers have a very important role that must be played with the aim that the learning we do in the classroom can be successful based on the learning objectives we have set before we begin the process of teaching and learning. The teachers' role which are discussed in this paper are: the teacher as the controller, the teacher as the organizer, the teacher as the assessor, the teacher as the prompter, the teacher as the participant, the teacher as the resource, the teacher as the tutor, the teacher as the observer, and the teacher as the performer. There fore, it is suggested that these roles have to be implemented by the teachers during teaching and learning, unless the teachers will not be success in their class. 


\section{References}

[1] Brown, D. (1994). Teaching by principles: an interactive approach to language pedagogy. USA: Prentice Hall Regents.

[2] Ricard L.A. Learning to Teach: 6th Edition. New York: McGraw-Hill Companies, Inc; 2004,

[3] Naibaho, L. Phonological Acquisition of A Child Suffering from Language Delay. International Journal of Language Education and Culture Review. 2 (1), 2016, 33-42.

[4] Harmer, J. How to Teach English: New Edition. England: Pearson Education Limited; 1998.

[5] Walter, E. Cambridge Advanced Learner's Ditionary. UK: Cambridge University Press. Third Edition; 2008.

[6] Harmer, J. The Practice of Eglish Language Teaching. England: Pearson Education Limited; 2001.

[7] McDonnell. The Experiential Library: Transforming Academic and Research Libraries through the Power of Experiential Learning. Kidlington: Chandos Publishing; 2017.

[8] Richad, Jack C \& Rodger TS. Approaches and methods in language teaching. Cambridge: Cambridge University Press; 2001.

[9] Gilbran. The Practice of English Language Teaching. England: Pearson Education Limited; 1991.

[10] Tyas, E. H., Sunarto, S., \& Naibaho, L. Evaluasi Implementasi Pembelajaran Students Centered Learning oleh Mahasiswa PPL Fkip-Uki di Sekolah Mitra-PSKD. Jurnal Selaras: Kajian Bimbingan dan Konseling serta Psikologi Pendidikan, 1 (1), 2018, 69-80.

[11] Naibaho, L. Peran Pendidikan dan Kebudayaan dalam Pembangunan Karakter dan Peradaban Bangsa Indonesia yang Majemuk. Jurnal the Ary Suta Center Series on Strategic Management, 27 (0), 2014. 69.

[12] Mann, T. The Oxford Guide to Library Research, $4^{\text {th }}$ Edition. New York: Oxford University Press; 2005.

[13] Mann, T. The Oxford Guide to Library Research, $3^{\text {rd }}$ Edition. New York: Oxford University Press; 2005.

[14] Goodman, D. V. Qualitative Research and the Modern Library. Cambridge: Chandos Publishing; 2011.

[15] George, W. M. The Elements of Library Research: What Every Student Needs to Know. New Jersey: Princeton University Press; 2008.

[16] Suryaningsih, L., Mastra, I. P., \& Naibaho, L. Optimizing the Air Transport Operations of Indonesian National Army-Air Force on Overcoming the Impact of the Future Natural Disasters. Journal of Advances in Social Science and Humanities, 4 (2), 2018.

[17] Lenburg. J. The Facts on File Guide to Research, $2^{\text {nd }}$ Edition. New York: An imprint of Infobase Publishing; 2010.

[18] Case, O. D. A Survey of Research on Information Seeking, Needs, and Behavior. Los Angles: Academic Press; 2002.

[19] Brown, D. Teaching by principles: an interactive approach to language pedagogy. USA: Prentice Hall Regents; 2006.

*Corresponding author.

E-mail address: lnaibaho68@yahoo.com 